\title{
Fostertest som prøvestein og brekkstang
}

\author{
Helsedirektoratets nylige anbefaling om å innføre ikke-invasiv prenatal testing i fosterdiagnostikken er svakt \\ begrunnet og i beste fall dårlig gjennomtenkt. I verste fall er det uttrykk for en kalkulert strategi for å semen- \\ tere fostermedisinernes rolle i den fremtidige svangerskapsomsorgen.
}

Over fire år etter at Universitetssykehuset Nord-Norge søkte om å få ta i bruk ikkeinvasiv prenatal testing (non-invasive prenatal testing, NIPT) i fosterdiagnostikken, har Helsedirektoratet nå kommet med sin anbefaling (1). Ved hjelp av en blodprøve fra kvinnen kan man sekvensere cellefritt DNA fra fosteret. Direktoratet anbefaler at man innfører denne metoden istedenfor morkake- og fostervannsprøve: «Metoden bør godkjennes som alternativ til morkakeprøve eller fostervannsprøve når KUB (kombinert ultralyd- og blodprøvetest, forfatternes anmerkning) viser høy estimert risiko for trisomi hos foster (veiledende $1: 250$ eller høyere)» (1).

Dette er stikk i strid med Bioteknologirådets anbefaling. Rådet gikk inn for å innføre ikke-invasiv prenatal testing som første undersøkelse for samme gruppe kvinner som i dag blir tilbudt fosterdiagnostikk. Testen ville altså erstatte dagens kombinerte ultralyd- og blodprøvetest (2).

Det kan virke på direktoratets brev som at den nye testen vil erstatte invasive tester (morkake- og fostervannsprøve), men det er ikke tilfellet. Ved positiv NIPT-resultat vil man likevel tilby invasiv test for å bekrefte eller avkrefte resultatet. Dette gir altså fire testnivåer. Først må du være i risikogruppen - her er alderskriteriet på 38 år det viktigste. Så følger kombinert ultralyd- og blodprøvetest. Deretter følger NIPT-test, og så til slutt en invasiv test dersom de foregående er positive og kvinnen ønsker det.

Anbefaler direktoratet testen fordi den er bedre? Her er Kunnskapssenterets svar: «Scenarioet med NIPT som sekundærtest til høyrisikopopulasjonen av gravide (risiko lik eller høyere enn 1:250) etter KUB-testen er både mer kostbar og gir dårligere effekt i form av færre oppdagede tilfeller trisomi enn dagens praksis» (3). Testen er altså dårligere og dyrere.

Hvorfor anbefale et dyrere opplegg? Direktoratet svarer at NIPT-bruk vil redusere antall morkake- og fostervannsprøver. Motivet er å redusere antall spontanaborter, som er en bivirkning av de invasive testene, angitt til rundt $0,5 \%$ (3). Helt konkret håper man å unngå 460 invasive prøver og 2,3 spontanaborter for en pris av kr 481875 per år (1). Det virker ikke som en overbevisende begrunnelse - all den tid man har argumentert så hardt med at ulempene med invasive tester er liten med dagens tilbud. I tillegg vet vi fra England at en del av dem som får positivt NIPT-svar, velger å ta abort uten først å ta en invasiv test (4). Altså vil ikke-affiserte fostre kunne bli abortert på grunn av falskt positive testsvar. Hvis hensikten virkelig er å forhindre abortering av friske fostre (5), enten som følge av den invasive testen eller falskt positive ikkeinvasive testsvar, så er den samlede gevinsten marginal.

\section{Argumentene}

Hvis det ikke er fordi testen er bedre, billigere eller har betydelig færre bivirkninger, hva er da grunnen til direktoratets anbefalinger? Trolig er dette den minst kontroversielle måten å innføre NIPT-metoden på. Forslaget til flertallet i Bioteknologirådet å erstatte den kombinerte ultralyd- og blod-

\section{«Dersom vi innfører teknologi bare fordi det er mulig, gjør vi oss til offer for tekno-}

\section{logitvang»}

prøvetesten med ikke-invasiv prenatal testing - vil utløse en debatt om "sorteringssamfunnet» fordi NIPT-testen nå internasjonalt anbefales brukt for å undersøke alle fosterets arveegenskaper (6) og ikke bare tre trisomier. Dessuten ville det gi utfordringer for de fostermedisinerne som har bygd opp kompetanse og karriere på tidlig ultralyd og kombinert ultralyd- og blodprøvetest: Ultralydundersøkelsen som kan supplere NIPT-testen, er mye mindre omfattende. I sin anbefaling har direktoratet innhentet uttalelser fra fostermedisinerne i bioreferansegruppen og fra tidligere fostermedisinere i samme gruppe, som sterkt anbefaler kombinert ultralyd- og blodprøvetest. Genetikerne i samme gruppe går derimot inn for å erstatte denne med ikkeinvasiv prenatal testing for høyrisikogruppen (1).

Et viktig argument er altså at Helsedirektoratet med sin anbefaling søker å unngå vanskelige helse- og fagpolitiske debatter. Men hva er gevinsten? Fostermedisinerne får ikke utvidet sitt virkefelt. Kvinnene kan ikke bedre «beskytte svangerskapet sitt» (1), da det eneste alternativet de tilbys, er en dårligere test med litt mindre risiko og mindre ubehag. Stammer anbefalingen fra behovet for å gi Universitetssykehuset Nord-Norge et svar? De har tross alt ventet i over fire år. Det kan dog ikke være grunnen. Direktoratet kunne ha svart at «NIPTtesten er et spennende redskap som har endret fosterdiagnostikken i mange land, og vi må derfor vurdere fosterdiagnostikken samlet».

En annen grunn er at denne overordnede diskusjonen er vanskelig og rokker ved hardt tilkjempede og sårbare ordninger. $\AA ̊$ innføre ikke-invasiv prenatal testing som en ekstra undersøkelse i tillegg til de andre vi har for samme formål, vil derfor løse et vanskelig problem. Men dersom vi innfører teknologi bare fordi det er mulig, gjør vi oss til offer for teknologitvang.

$\AA ̊$ innføre ikke-invasiv prenatal testing som «erstatning» for invasive tester kan få følger for bruken av testen på andre områder. Argumentene vi bruker nå blir prøvestein for fremtidige diskusjoner om NIPTbruk. Men kanskje viktigere er at de kan bli brukt som brekkstang: «Vi bruker jo NIPT til å finne trisomi 21, som mange jo ikke oppfatter som svært alvorlig medisinsk sett, så da må vi jo kunne bruke NIPT til X, som er langt mer alvorlig.»

Teknologi er en effektiv måte å virkeliggjøre verdier på. Samtidig kan teknologien endre våre verdier. Det er derfor viktig at vi bruker ny teknologi for gode formål med gode begrunnelser. NIPT-testen er en kraftfull teknologi som krever mer enn en tannløs eller taktisk begrunnelse.

\section{Bjørn Hofmann}

bjoern.hofmann@ntnu.no

Ketil Slagstad

Bjørn Hofmann (f. 1964) er professor i medisinsk filosofi og etikk ved Norges teknisk-naturvitenskapelige universitet på Gjøvik og ved Universitetet i Oslo.

Forfatter har fylt ut ICMJE-skjemaet og oppgir følgende interessekonflikter: Han er medlem av Bioteknologirådet.

Ketil Slagstad (f. 1983) er lege og medisinsk redaktør i Tidsskriftet.

Forfatter har fylt ut ICMJE-skjemaet og oppgir ingen interessekonflikter. 


\section{Litteratur}

1. Helsedirektoratet. Helsedirektoratets tilrådning Bruk av Non-invasive prenatal testing (NIPT) for påvisning av trisomi 13, 18 og 21. 23.1.2017. Oslo: Helsedirektoratet, 2017.

2. Bioteknologirådet. Fosterdiagnostikk: NIPT for å undersøke trisomi hos fosteret. 4.10.2016. Oslo: Bioteknologirådet, 2016.

3. Juvet LK, Ormstad SS, Schneider AS et al. Ikke invasiv prenatal testing (NIPT) for påvisning av trisomi 21, 18 og 13. Oslo: Folkehelseinstituttet, 2016.

4. Chitty LS, Wright D, Hill M et al. Uptake, outcomes, and costs of implementing non-invasive prenatal testing for Down's syndrome into NHS maternity care: prospective cohort study in eight diverse maternity units. BMJ 2016; 354: i3426.

5. Hov GG, Asberg A, Thorstensen K. Bedre spesifisitet gir mindre skade av friske fostre. Tidsskr Nor Legeforen 2014; 134: 266.

6. Chen SC, Wasserman DT. A Framework for Unrestricted Prenatal Whole-Genome Sequencing: Respecting and Enhancing the Autonomy of Prospective Parents. Am J Bioeth 2017; 17: 3-18.

Mottatt 29.1. 2017, første revisjon innsendt 8.2. 2017, godkjent 16.2. 2017. En av forfatterne er redaktør i Tidsskriftet. Manuskriptet er derfor behandlet eksternt av setteredaktør Guri Rødveit.

Publisert først på nett. 